\title{
Determinants of Choice of Joint Venture Arrangements for International Marketers
}

\author{
Ifediora Chuka Uzoma \\ Department of Marketing, \\ University of Nigeria, Nigeria \\ E-mail: chuka.Ifediora@unn.edu.ng \\ Ugwoke Pius \\ Department of Marketing \\ University of Nigeria, Nigeria \\ Ifediora Raluchukwu Ifeoma \\ Doctoral Candidate, \\ Department of Educational Administration and Planning, \\ Ebonyi State University, Abakaliki, Nigeria \\ E-mail: raluchukwul@gmail.com \\ Ugwuanyi Chidera Christian \\ Department of Marketing \\ University of Nigeria, Nigeria \\ E-mail: chidera.ugwuanyi@unn.edu.ng
}

\begin{abstract}
This study investigated the determinants of the choice of joint venture arrangements for international marketers in Nigeria. The study aims at identifying the most significant influences on the choice of joint venture arrangements. The survey research design was used for the study. The study was carried out in South-east, Nigeria. A sample of 50 experienced international marketers was selected for the study using a snowball sampling technique. Data was gathered through the use of a structured questionnaire.. The analysis was done using Principal Component Analysis. Findings reveal that brand name/equity, firm size, market attractiveness, research and development, as well as internationalization strategy are the most significant determinants of the choice of joint venture arrangements which international marketers in Nigeria adopt. The study recommends that prospective international marketers consider these factors before or when seeking an alliance with any foreign company an international markets.
\end{abstract}

Keywords: Joint Venture, Strategic Alliance, International Markets, International Marketers.

\section{Introduction}

As the doors to world markets become freely open to one another due to the waves of globalization, companies around the world markets increasingly move their operations from the domestic marketplace to international markets. Their choice of market entry mode has been one of the most critical elements of a firm's foreign investment strategy (Nakos and Brouthers, 2002; Kumar and Subramaniam, 1997). In conquering foreign market regulations and barriers, firms now choose to establish alliances with local companies (Guidice and Mero, 2007). They use this entry mode as their choice to access markets and resources worldwide. Such alliances can be defined as a medium and long-term agreement; it is between businesses, which entail the mutual transfer of intangible resources such as technology or human skills with or without the development of a reserved administrative structure (Oxley, 1997). Once companies decide to move internationally with a partner, they can either apply the equity form (joint ventures) or a non-equity form (non-equity alliances).

Various studies have tried to explore factors that could explain the choice of these firms seeking an international alliance. Alvarez (2003) for instance, proposes that a firm is likely to invest in a wholly-owned subsidiary if it (i.e., the firm) is sufficiently large, has had substantial experience in the host country geographical region and have good experience in the international sphere. This same author also gave a puzzling remark opining that joint venture may be chosen by a company if the possible host nation is perceived to imply a high level of instability and uncertainty or has a high rate of growth. The contention 
here is that some regulations like the indigenization policy of Nigeria in I97I which could be raised in host countries may defeat this Alvarez's(2003) proposition of joint venture arrangement (Ogbuagu, I983). Meanwhile, some empirical evidence like Majocchi et al. (2010) avail that the host country institutional characteristics coupled with the cultural distance on alliance mode choice can be very erratic not to talk of the firm's specific characteristics which Alvarez (2003) advocates for. Despite the moderating probability of choosing joint venture forms which are conditioned upon firm-specific characteristics of the investment firm as well as country-specific characteristics of the country of investment, Agarwal (I994) insistently alludes that firms may choose joint venture forms overseas mainly when they are confronted with high socio-cultural distance. This paper, therefore, seeks to empirically address the determining factors for the choice of joint venture arrangements among international marketers in Nigeria when taking their businesses abroad.

\section{I.I Objective of the Study}

The main goal of the study is to harness the determinants of the choice of joint venture arrangements for international marketers. The specific objective, therefore, is to ascertain the most significant factors for the choice of joint venture arrangements for international marketers in Nigeria.

\section{Conceptualization \\ 2.I Joint Venture}

For many decades ago, the concept of joint venture has been in use very increasingly. Apart from numerous books published on the subject, a significant number of articles have been written on the various aspects of joint ventures. Unfortunately, these research publications have not adopted a uniform definition to describe the term "Joint Venture". Some research authors define it as a cooperative enterprise entered into by two or more business entities for a particular project or other business activity (Kumar and Subramaniam, 1997). Often, a joint venture gives rise to a separate business entity, to which the owners contribute assets, have equity, and agree on how this entity may be managed. Another research author describes joint venture as a business enterprise embarked on by two or more individuals or organizations to share the expense and (expectedly) profit of a particular business project (Kayo et al., 2010). Some research scholars advocate that a joint venture may not be necessarily a business enterprise regarding a proprietorship, partnership, or corporation; instead, it is an agreement between parties for a specific purpose and usually a defined timeframe (Hauswald and Hege, 2006). Joint ventures may be informal, such as a handshake and an agreement for two firms to share a booth at a trade show for instance. Other arrangements may be highly complex, such as a collection of significant electronics firms joining to produce new microchips for example. The primary element in a joint venture partnership is its single, definable objective (Agarwal, 1994). Joint ventures have increased in popularity in recent years despite the comparably high failure rate of efforts at building one consequent to one reason or the other.

Developing countries see joint ventures as one of the best instruments for meeting the competing interests of national development and the prevention of the domination of the economy by foreign investors (Sornarajah, 1992). Studies have also shown that in developing countries, joint venture investments have been more successful than foreign investments made through other means (Beamish 1988). For American based companies, cooperative arrangements such as joint ventures in developed countries outnumber wholly owned foreign subsidiaries by a margin of four to one (Contractor and Lorange, I988). Killing (1983) found that Japanese and European firms preferred joint ventures as a mode of entry into developing countries than did American firms. This, however, changed in the second half of the eighties and the Americans are equally enthusiastic about forming joint ventures in the developing countries (Awadzi, 1987).

Given these preceding claims, it shows that there is a different kind of joint venture arrangements such as equity or non-equity alliance as some extant literature posit (Oxley, I997; Luo, 2013). The former provides that the partnering firms have $50-50$ ownership, but in the latter, it is a form of an acquisition or a wholly-owned subsidiary arrangement as the case may be. In either case, there is yet the need to address factors determining the choice of joint venture arrangements applicable to international marketers in Nigeria.

\section{Theoretical Framework}

The theoretical explanation for how firms choose their joint venture arrangements when taking their businesses to international markets has been viewed from diverse theoretical perspectives. Some existing studies explained it using Williamson's (1975) Transaction Cost Economics (Luo, 2013)while some use the Resource-Based View. However, some existing studies use the combination of both (Majocchiet al., 2010; Alvarez, 2003). Some studies tackled it from the perspective of the Agency theory (McConnell and Servaes, 1995) and contingency approach (Agarwal, 1994) while Kayo et al. (2010) strongly support the learning view of the firm's choice showing that a firm's previous experience in a particular strategy (say - joint ventures) is significant enough to determine its future choice for the same strategy as a route to grow.

Now, in building a theoretical knowledge boundary for this current study, each or any of the above theoretical perspectives offer specific importance for explaining the choice of joint venture arrangements which international marketers in 
Nigeria may adopt when taking their businesses abroad. Therefore, holding to only one or just any one of these theories may limit this study to the domain of understanding as proposed by the chosen theoretical perspective. In other words, since the various determinants of the choice of joint venture arrangements for international marketers are multidimensional, it is plausible to use the mix of these theories just as Majocchiet al. (2010) and Alvarez (2003) combined RBV with TCE.

\section{Review of Empirical Studies}

Quite some studies have been done in the past on determinants of choice of joint venture arrangements. For instance, Alvarez (2003) did a study directed toward investigating determining factors for choosing wholly-owned subsidiaries or Joint Ventures among Catalan Multinational Manufacturing companies. The goal of the study was primarily to investigate factors influencing the choice between establishing a wholly-owned subsidiary or entering into a joint venture (JV) as made by Catalan manufacturing firms investing abroad. Results show that a Catalan production company is more likely to set up a wholly-owned subsidiary if the enterprise is indisputably big, has had substantial experience in the host country geographical region, but is young and possesses small general experience in the international scene.

On the other hand, a Catalan company is more likely to invest through a wholly owned subsidiary (WOS) if the company owns intangible or tacit assets and functions within a technologically advanced sector. Finally, a joint venture is preferred by a Catalan firm if the potential host country is perceived to have a high level of instability and risk or has a high growth rate. Majocchiet al. (2010) also did a similar study but among Italian firms. These authors investigated the factors affecting the choice between joint ventures and non-equity alliances as Italian firms enter foreign markets. Their findings expose the important role played by firm size and by institutional and political features of host countries. The results concerning the role of functional activities involved and the industrial sector are mixed. The overall findings showed that it is necessary to develop a more integrated approach to understand this difficult choice made by firms when expanding abroad. Kayo et al. (2010) also made a study choice of joint ventures arrangements considering acquisitions, joint ventures, or arm's-length alliances choices. The study was carried out in Brazil. It analyses the determinants of choice among different firm growth strategies: acquisitions, joint ventures, or arm's-length alliances. Their findings support the learning perspective of the firm's choice showing that a firm's previous experience in a specific strategy (e.g., joint ventures) is significant to determine its future choice for the same strategy as a path to grow. Agarwal (1994) also did a study on U.S. firms investigating the effect of socio-cultural distance and the choice of joint ventures using the contingency perspective. To him, he believes that firms adopt joint venture arrangements internationally when faced with high socio-cultural distance. However, the probability of choosing the joint venture arrangement is expected to be influenced by the firm-specific characteristics of the investing firm as well as countryspecific characteristics of the country of investment. This study examines the moderating role of some firm-and country-specific variables on a firm's preference for joint venture arrangement in response to socio-cultural distance. The firm-specific variables examined in this study include: size, multinationality and technological depth; and country-specific factors examined in the study include country risk and market potential. By using the data gathered from a sample of U.S. manufacturing firms, findings indicated the usefulness of the contingency approach for modeling choice of joint ventures.

Another essential previous related study is the work of Hauswald and Hege (2006) on ownership and control in joint ventures. By analyzing the determinants of ownership in US joint ventures, the study finds that the higher the potential for single value extraction, the more parents prefer equal shareholdings regardless of their attributes. Similarly, parent-specific spillovers make 50-50 ownership more attractive to the detriment of single control, whereas complementarities in parent resources have the opposite effect.

\section{Observed Gaps in the Reviewed Literature}

Of all the existing studies carried out in the past which were reviewed in the preceding section, very few or none is done in the context of Nigerian joint ventures, yet there is currently a growing number of strategic alliances between Nigerian companies and foreign investors especially from Asia like the Sino-Nigerian relations. The consequence of this is that there is a paucity of research works on joint ventures between Nigerian companies and foreign investors. Neither are there studies on determinants of choice of joint venture arrangements for Nigerian international marketers. Moreover, a good number of Nigerian businessmen and women are currently craving to make their businesses gain international presence sequel to the current export promotional policies of present government administration. In this regard, it becomes pertinent to replicate the existing studies in the Nigerian context to know which determining factors is the most significant determinant of the choice of joint venture arrangements international marketers in Nigeria adopt mostly.

Table I: Meta-Analysis of the Factors Determining Choice of Joint Venture Arrangements

\begin{tabular}{ll}
\hline Determinants of Choice of Joint Venture & Authors \\
\hline Firm size (assets, sales, employees) & $\begin{array}{l}\text { Kogut and Singh (1988), Makino and Neupert (2000), } \\
\text { Brouthers and Brouthers (200I) }\end{array}$ \\
\hline
\end{tabular}




\begin{tabular}{|c|c|}
\hline International Experience & $\begin{array}{l}\text { Gatignon and Anderson (1988), Madhok (1998), } \\
\text { Padmanabhan and Cho (1999) }\end{array}$ \\
\hline $\begin{array}{l}\text { Technological Advantages } \quad \text { (Generally R\&D } \\
\text { expenditure/sales) Also subjective perceptions such as asset } \\
\text { specificity, asset tacitness, }\end{array}$ & $\begin{array}{l}\text { Gomes-Casseres (1990), Fagre and Wells (I982), Lecraw } \\
\text { (1984) }\end{array}$ \\
\hline $\begin{array}{l}\text { Marketing and Product Differentiation Advantages } \\
\text { (Generally Advertising expenditure/sales, also Perceived } \\
\text { Importance of Product Quality or Brand }\end{array}$ & $\begin{array}{l}\text { Erramilliet al., (1997), Agarwal and Ramaswami (1992), } \\
\text { Pan and Tse (2000) }\end{array}$ \\
\hline Socio-cultural Distance & Asiedu and Esfahani (200I), Pla (1999), Pan (1996) \\
\hline $\begin{array}{l}\begin{array}{l}\text { Economic or Political risk (volatility of operating } \\
\text { environment) }\end{array} \\
\end{array}$ & Kim and Hwang (I992), Madhok (I998) \\
\hline Country size or growth (Generally an Attractive Market) & $\begin{array}{l}\text { Hennart (I99I), Makino and Neupert (2000), Brothers et } \\
\text { al. (1996) }\end{array}$ \\
\hline $\begin{array}{l}\text { Firm resources, Host country characteristics, Industry sector, } \\
\text { Internationalisation strategy, Activities of Value-chain }\end{array}$ & Majocchiet al., (2010) \\
\hline
\end{tabular}

Source: Researchers' Compilation

\section{Methodology}

Survey research design methodology was adopted for this study. The study was carried out in southeast Nigeria, specifically among Nigerian international marketers who also are exporters. A sample of 50 international markets was selected for this study across the five (5) southeastern states in Nigeria using a snowball sampling technique. The Nigerian Export Promotion Council in Enugu State was used as the starting point for identifying and selecting international marketers. A structured questionnaire was adopted for data collection in this study. The questionnaire was validated using content validity method and its reliability was ascertained using Cronbach's Alpha method of testing internal consistency. The questionnaire was confirmed reliable at 0.79 standardized Alpha using the Nunnally and Bernstein's (1964) benchmark threshold. Principal Component Analysis, which is a method of Factor Analysis, was used to test the hypothesis formulated for this study.

\section{Results and Discussions}

Out of the copies of a questionnaire administered in the survey conducted for this study, only 44 copies were completed. Six copies were not completed. Some of them were not returned, but in all, the copies returned provide success response rate of $88.0 \%$. The demographic data of the respondents was presented here below.

Table 2: Respondents' Demographic Data

\begin{tabular}{|c|c|c|c|c|c|}
\hline & Frequency & Percent & & Frequency & Percent \\
\hline \multicolumn{3}{|c|}{ Gender Distribution } & \multicolumn{3}{|c|}{ Years of Experience in International Business } \\
\hline Male & 29 & $65.9 \%$ & $<5$ yrs & 7 & $15.9 \%$ \\
\hline Female & 15 & $34.1 \%$ & $5-9 y r s$ & 15 & $34.1 \%$ \\
\hline \multirow[t]{2}{*}{ Total } & 44 & $100.0 \%$ & $\mathrm{I} 0-\mathrm{I} 4 \mathrm{yrs}$ & 18 & $40.9 \%$ \\
\hline & & & $\geq 15 y r s$ & 4 & $9.1 \%$ \\
\hline \multicolumn{2}{|c|}{ Education Qualification } & & Total & 44 & $100.0 \%$ \\
\hline FSLCert. & 0 & $0.0 \%$ & & & \\
\hline O’Level & 2 & $4.5 \%$ & \multicolumn{3}{|c|}{ Int'l Mkters Captured from Southeast } \\
\hline $\mathrm{OND} / \mathrm{NCE}$ & $\mathrm{I3}$ & $29.5 \%$ & Abia & 13 & $29.5 \%$ \\
\hline $\mathrm{BSc} / \mathrm{HND}$ & 23 & $52.3 \%$ & Anambra & 9 & $20.5 \%$ \\
\hline Postgraduate & 6 & $13.6 \%$ & Ebonyi & 5 & II.4\% \\
\hline \multirow[t]{3}{*}{ Total } & 44 & $100.0 \%$ & Enugu & II & $25.0 \%$ \\
\hline & & & Imo & 6 & $13.6 \%$ \\
\hline & & & Total & 44 & $100.0 \%$ \\
\hline
\end{tabular}

Source: Field Survey

The data presented through table 2 above represents the demographic data of the respondents. I3(29.5\%) of them were captured from Abia state, 9(20.5\%) were captured from Anambra state, 5(II.4\%) from Ebonyi state, II(25.0\%) from Enugu state while 6(I3.6\%) others were captured from Imo state. As for their gender distribution, 29(65.9\%) of them are males while $15(34.1 \%)$ others are females. The data on their education qualification shows that $2(4.5 \%)$ of them are holders of $\mathrm{O}$ 'Level, I3(29.5\%) are holders of OND/NCE, 23(52.3\%) are holders of BSc/HND while 6(I3.6\%) others are holders of 
Postgraduate degree. Considering the respondents' years of experience in international business, 7(15.9\%) of them indicated that they are having < 5years of experience, I5(34.I\%) of them said they have $5-9$ years' experience, I8(40.9\%) agreed that they have 10 - I4 years' experience while the remaining $4(9.1 \%)$ others said they have $\geq 15$ years' experience.

The implication of the data gathered on 'years of experience in international business' is to know if the international marketers captured in the survey are the ones with good experience of making joint venture arrangements with foreign businesses. With the data gathered, it would be noted that the majority of them are actually with good experience.

\section{I Test of Hypothesis}

To determine the most significant determining factors for the choice of joint venture arrangements for international marketers in Nigeria, the data gathered from the sample of international marketers are used. The data were subjected to test using Principal Component Analysis, which is a method of Factor Analysis. The test was run through SPSS version 17.0. The result of the test is presented here.

Table 3: Total Variance Explained

\begin{tabular}{|c|c|c|c|c|c|c|}
\hline \multirow[b]{2}{*}{ Component } & \multicolumn{3}{|c|}{ Initial Eigenvalues } & \multicolumn{3}{|c|}{ Extraction Sums of Squared Loadings } \\
\hline & Total & $\%$ of Variance & Cumulative \% & Total & $\%$ of Variance & Cumulative \% \\
\hline $\mathrm{I}$ & 2.687 & 20.666 & 20.666 & 2.687 & 20.666 & 20.666 \\
\hline 2 & 2.312 & 17.785 & $38.45 \mathrm{I}$ & $2.3 \mathrm{I} 2$ & 17.785 & $38.45 \mathrm{I}$ \\
\hline 3 & 1.901 & I4.62I & 53.073 & I.90I & I4.62I & 53.073 \\
\hline 4 & 1.445 & II.I16 & 64.189 & I.445 & II.II6 & 64.189 \\
\hline 5 & I.III & 8.547 & 72.736 & I.III & 8.547 & 72.736 \\
\hline 6 & .963 & 7.408 & 80.144 & & & \\
\hline 7 & .762 & 5.860 & 86.004 & & & \\
\hline 8 & .577 & $4.44 \mathrm{I}$ & 90.445 & & & \\
\hline 9 & .502 & 3.865 & 94.309 & & & \\
\hline 10 & .402 & $3.09 \mathrm{I}$ & 97.401 & & & \\
\hline II & .176 & 1.353 & 98.754 & & & \\
\hline $\mathrm{I} 2$ &. $\mathrm{II3}$ & .870 & 99.624 & & & \\
\hline $\mathrm{I3}$ & .049 & .376 & I00.000 & & & \\
\hline Extraction & ethod: 1 & incipal Compo & it Analysis. & & & \\
\hline
\end{tabular}

Table 3 above presents the total variance explained by the components extracted. Out of the I3 components measured, five components were extracted. These components represent $72.736 \%$ total cumulative percentage.

Table 4: Component Matrix

\begin{tabular}{llllll}
\hline \multicolumn{7}{c}{ Component } \\
\hline & $\mathrm{I}$ & 2 & 3 & 4 & 5 \\
\hline Firm Size & .085 & -.657 & .582 & .133 & -.035 \\
\hline International Experience & -.357 & .514 & -.494 & -.417 & .027 \\
\hline Research \& Development & -.263 & -.074 & .174 & .634 & .270 \\
\hline Asset Tacitness & .389 & .028 & -.651 & .395 & .130 \\
\hline Advertising Expenditure & .118 & .599 & .442 & .214 & .385 \\
\hline Product Quality & -.237 & .613 & -.343 & .459 & .070 \\
\hline Brand Name/Equity & .776 & -.024 & .027 & -.183 & .336 \\
\hline Socio-cultural Distance & .717 & -.035 & -.096 & .262 & .275 \\
\hline Economic or Political Risk & .750 & .259 & .131 & -.368 & .113 \\
\hline Market Attractiveness & -.077 & .690 & .551 & -.231 & .095 \\
\hline Firm Resources & -.427 & .291 & .399 & .113 & .076 \\
\hline Industry Sector & -.496 & -.392 & -.017 & -.130 & .546 \\
\hline Internationalization Strategy & -.385 & -.301 & -.245 & -.345 & .593 \\
\hline Extraction Method: Principal Component Analysis. & & \\
\hline a. 5 components extracted. & \multicolumn{5}{c}{} \\
\hline
\end{tabular}


The five (5) components extracted are specified in table 4 above. Using the factor loadings of each component, it would be noticed that the first component is loaded more on Brand Name/Equity, the second component is loaded more on Market Attractiveness, the third component is loaded more on Firm Size, the fourth component is loaded more on Research \& Development while the fifth component is loaded more on Internationalization Strategy.

Based on this result, it shows that the most significant determinants of the choice of joint venture arrangements which international marketers in Nigeria agreed to are Brand Name/Equity, Market Attractiveness, Firm Size, Research \& Development and lastly, Internationalization Strategy. These are consistent extant studies like Erramilliet al., (I997), Agarwal and Ramaswami (1992), Pan and Tse (2000) ob Brand Name/Equity; Hennart (I99I), Makino and Neupert (2000), Brothers et al. (1996) on Market Attractiveness; Kogut and Singh (I988), Makino and Neupert (2000), Brouthers and Brouthers (200I) on Firm Size; Gomes-Casseres (1990), Fagre and Wells (I982), Lecraw (I984) onResearch \& Development; and Majocchiet al. (2010) on internationalization strategy,

\section{Conclusion and Recommendation}

Determinants of the choice of joint venture arrangements are multidimensional. Firms that seek international presence do so with a specific goal to be achieved.. Therefore, it is ideal to conclude that the most significant determinants of the choice of joint venture arrangements for international marketers in Nigeria are marketing and product differentiation advantage (brand name/equity), firm size, market attractiveness, the technological advantage (research \& development) and internationalization strategy. It is recommended that prospective international marketers consider these factors before or when seeking an alliance with any foreign company in international markets.

\section{References}

Agarwal, S. (1994). Socio-Cultural Distance and the Choice of Joint Ventures: A Contingency Perspective. Journal of International Marketing, 2(2), 63-80

Agarwal, J. P. and Ramaswami, S. (I992). Choice of Foreign Market Entry Mode Form: The Impact of Ownership, Location and Internalization, Journal of International Business Studies, Ist. Quarter, I-27.

Alvarez, M. (2003). Wholly-Owned Subsidiaries Versus Joint Ventures: The Determinant Factors in the Catalan Multinational Manufacturing Case. Institut d'Economia de Barcelona (IEB)., Working Pa, I-27.

Asiedu, E. and Esfahani, H.S. (200I). Ownership Structure in Foreign Direct Investment Projects, Review of Economics and Statistics, 83,4, 647-662.

Awadzi, W.K. (1987). Determinants of Joint Venture Performance: A Study of International Joint Ventures in the United States.Ph. D Dissertation, Louisiana State University and Agricultural and Mechanical College, U.S.A.

Beamish, P.W. (1988).Multinational Joint Ventures in Developing Countries.Routledge, New York.

Brouthers, K. and Brouthers, L. (200I). Explaining the National Cultural Distance Paradox, Joumal of International Business Studies, 32,I, I77-189.

Brouthers, K., Brouthers, L.and Werner, S. (1996). Dunning's Eclectic Theory and the Smaller Firm: The Impact of Ownership and Locational Advantages on the Choice of Entry-Modes in the Computer Software Industry, International Business Review, 5,4, 377-394.

Contractor, F.J. and Lorange, P. (1987). Cooperative Strategies in International Business, Lexington Press, U.S.A.

Erramilli, M., Agarwal, S. and Kim, S. (1997). Are Firm-Specific Advantages Location- Specific Too? Journal of International Business Studies, 4th quarter, 735-758.

Gatignon, H and Anderson, E. (1988), “The Multinational Corporation's Degree of Control over Foreign Subsidiaries: An Empirical Test of a Transaction Cost Explanation, Journal of Law, Economics and Organization, 42, 305-336

Gomes-Casseres, B. (1990). Firm Ownership Preferences and Host Government Restrictions: An Integrated Approach, Journal of International Business Studies, Ist quarter, I-24.

Guidice, R.M., and Mero, N. (2007). Governing Joint Venture: Tension among Principals' Dominant Logic on Human Motivation and Behaviour. Journal of Management and Governance, I I(3): 26I-283.

Hauswald, R.B.H. and Hege, U., (2006). Ownership and Control in Joint Ventures: Theory and Evidence. AFA 2004 San Diego Meetings. Available at SSRN: https://ssrn.com/abstract=302924

Hennart, J. F. (I99I). The Transaction Costs Theory of Joint Ventures: An Empirical Study of Japanese Subsidiaries in the United States, Management Science, 37, 483- 497.

Kayo, E. K., Kimura, H., Patrocínio, M. R., \& Neto, L. E. de O. (2010). Acquisitions, Joint Ventures or Arm’s-Length Alliances? Analyzing the Determinants of the Choice of Growth Strategy in Brazil from 1996 through 2007. BAR Brazilian Administration Review, 7(4), 397-412. https://doi.org/I0.1590/SI807-76922010000400006

Killing, J.P. (1983). Strategies For Joint Venture Success. Praeger, New York. 
Kim, W, and P. Hwang (1992). Global Strategy and Multinationals Entry Mode Choice, Journal of International Business Studies, Ist quarter, 29-53

Kogut, B., and Singh, H. (1988). The Effect of National Culture on the Choice of Entry Mode. Journal of International Business Studies, I9(3): 4I I-432

Kumar, V., \& Subramaniam, V. (I997). A Contingency Framework for the Mode of Entry Decision. Journal of World Business, 32(I): $53-72$

Lecraw, D. (1984). Bargaining Power, Ownership, and Profitability of Transnational Corporations in Developing Countries, Journal of International Business Studies, Spring/summer, 27-43

Luo, W. (2013). Locational Determinants and Equity-Based Entry Mode Choice in the Forest Sector: the Case of China.

(Unpublished) Thesis Submitted for an MSc Degree in Faculty of Agriculture and Forestry University of Helsinki, I-73. https://doi.org/I0.I080/02827581.2014.920908

Majocchi, A., Mayrhofer, U., \& Camps, J. (2010). The Choice between Joint Ventures and Non-Equity-Alliances: Evidence from Italian Firms. Proceedings of 36th Annual EIBA (European International Business Academy) Conference, 23. Retrieved from http://halshs.archives-ouvertes.fr/halshs-006902I6

Madhok, A. (1998). The Nature of Multinational Firm Boundaries: Transaction Costs, Firm Capabilities, and Foreign Market Entry Mode, International Business Review, 7, 259-290.

Makino, S. and Neupert, K. (2000), National Culture, Transaction Costs, and the Choice between Joint Venture and Wholly Owned Subsidiary, Joumal of International Business Studies, 3I, 4, 705-7I3.

McConnell, J. J., and Servaes, H. (1995).Equity Ownership and the Two Faces of Debt.Journal of Financial Economics, 39(I), I3I-I57.

Nakos, G., and Brouthers, K.D. (2002). Entry Mode Choice of SMEs in Central and Eastern Europe. Entrepreneurship Theory and Practice, 27 (I): $47-64$

Ogbuagu, C.S.A. (1983). The Nigerian Indigenization Policy: Nationalization or

Pragmatism? African Affairs, 82(327): 24I - 266

Oxley, J.E. (1997). Appropriability Hazards and Governance in Strategic Alliances: A Transaction Cost Approach. Journal of Law, Economics and Organization, I3 (3): 387-409.

Padmanabhan, P. and Cho, K. (1999). Decision Specific Experience in Foreign Ownership and Establishment Strategies: Evidence from Japanese Firms, Journal of International Business Studies,30, I, 25-44

Pan, Y. (1996). Influences on Foreign Equity Ownership Level in Joint Ventures in China, Journal of International Business Studies, Ist quarter, I-26.

Pan, Y. and Tse, D. (2000). The Hierarchical Model of Market Entry Modes, Journal of International Business Studies, 3 I,4, 535-554

Pla, J. (1999). Filiales y entrada en los mercados internacionales.Factores determinantes, Revista de EconomíaAplicada, No.20, vol. VII, 29-5I.

Sornarajah, M. (1992) - Law of International Joint Ventures, Longman, Singapore.

Williamson, O. E. (1975), Markets and Hierarchies, New York: The Free Press.

\section{Copyrights}

Copyright for this article is retained by the author(s), with first publication rights granted to the journal. This is an open-access article distributed under the terms and conditions of the Creative Commons Attribution license (http://creativecommons.org/licenses/by/4.0/). 